\title{
The Importance of Operating Budgets in Estimating the Revenues and Expenses in the Industrial Companies Operated in the Aqaba Special Economic Zone
}

\author{
Authority \\ Dr. Lu'ay Mohammad Abdel-Rahman Wedyan \\ Department of Administrative and Financial Sciences, Al Balqa Applied University \\ Al-hosun University College \\ E-mail: wedyanluai1@yahoo.com
}

Muneer Mohamad Falah Jaradat (Corresponding author)

Department of Administrative and Financial Sciences, Al Balqa Applied University

Al-hosun University College

E-mail: mune_2000@yahoo.com

Dr. Mohammad Mahmoud Mohammad Bshayreh

Department of Administrative and Financial Sciences, Al Balqa Applied University

Al-hosun University College

E-mail:mbsh1979@yahoo.com

Received: November 27, 2016 Accepted: December 21, 2016 Published: January 02, 2017

doi:10.5296/ijafr.v6i2.10360 URL: http://dx.doi.org/10.5296/ijafr.v6i2.10360

\begin{abstract}
The study aimed to investigate the importance of budgets in estimating the revenues and expenses in the industrial companies operated in the Aqaba Special Economic Zone Authority as an attempt to find the solution and recommendations which increase the budgets efficiency in estimate of revenues and expenses. The researchers designed a questionnaire for collecting needed data; the questionnaires were analyzed statistically to test the hypotheses and
\end{abstract}


analyzed the results.

The most important of the study's results; that the budgets are a financial and quantitative achievement of the objectives, There is an organizational and accounting structure to identify the items of the operating activities in the budgets, using budgets leads to distributing the available resources on the productive departments accurately and in preparing budgets, there is a standard costs system for identifying the production costs as well as the operating activities.

The recommendations of this study represent in use the statistical methods in estimating the revenues and costs when preparing the operating budgets, the revenues budget (income) should be taken care of and it should be considered as the main tool for linking all the production activities with the operating objectives, budgets should be prepared in an organizational and accounting structure and depend on all the administrative levels in identifying the available resources on the operating activities

Keywords: Budgets, Standard costs, Revenues, Expenses, Industrial companies, Aqaba economic zone, Jordan

\section{Introduction}

Budgets are one of the most important tools used in planning, controlling, performance evaluation and decision make, also budgets are an integral part in the internal system of the industrial companies and the tool used by the company to achieve its main objectives for maximizing profits and revenues; it is an accounting tool or plan for what the administrative levels can do to achieve success at the market and try to meet the needs of customers as well as an important method used by the management accounting.

Budgets provide a general look for what the company can be in the future, so the company can guarantee its constant growth since budgets give the general perception of both the internal and external changes facing companies. Accordingly, the company will be able to achieve goals and avoid any inappropriate changes resulting from different circumstances in the environment surrounding it.

Given the importance of budgets in planning and controlling for the future activities and making operating decisions, the researcher examined the importance of the operating budgets in estimating the revenues and expenses in the operating industrial companies in the Aqaba special economic zone and identified the most important foundations of budgets to reach to objectives related to the growth of the industrial companies.

\subsection{Methodology of the Study}

To investigate the importance of budgets in estimating the revenues and expenses in the industrial companies operated in the Aqaba Special Economic Zone Authority, in data analysis the study based on a descriptive analytical method, and to get the primary data required to test the study hypothesis, a study questionnaire was designed and distributed on 


\section{MIN Macrothink}

International Journal of Accounting and Financial Reporting

ISSN 2162-3082

2016, Vol. 6, No. 2

the sample's elements who represent the industrial companies working in Aqaba special economic zone authority.

\subsection{Hypotheses of the Study}

This study tries to answer the following questions;

1- Are the operating budgets considered a quantitative and financial translation of the objectives the administration seeks to reach?

2- Is there an accounting and organizational structure to identify the items of the operating activities in the budgets?

3- Does using budgets lead to distributing the available resources to the production departments accurately?

4- In preparing budgets, is there a system for the standard costs to identify the costs of production and operating activities?

\subsection{Objectives of the Study}

This study attempts to achieve the following objectives;

1- Identifying the budgets, aims and importance of applying them in industrial companies.

2- Identifying the importance of budgets as a real financial and quantitative application of the objectives set by the administration in the industrial companies.

3- Identifying the importance of the organizational and accounting structure in identifying the items of the operating activities in the budgets system in the industrial companies.

4- Identifying the importance of the standard costs in setting the production costs and the activities related to it in the industrial companies.

5- Identifying the budgets' role in distributing the available resources of the company.

\subsection{Important of the Study}

The budgets provide a comprehensive plan covering all the different activities in the company during a future financial period, that representing a quantitative and financial translation of each administrative objective and they have a controlling role on activities, operations and identifying the efficiency of departments in achieving certain tasks leading to achieving the planned objectives in a high degree of efficiency.

From the above, it is evident that the importance of this study is for exploring the importance of the operating budgets in estimating the revenues and expenses in the industrial companies operating in Aqaba special economic zone in terms of achieving the quantitative and financial objectives, the accounting and organizational structure, the system of the estimated costs, distribution of the available resources and its importance as a result of few studies examining 
the budgets towards different activities in the company.

\section{Literature Review}

\subsection{Moayad Al-Fadhil study (1994)}

This study examined the participation subjects in preparing budgets in an attempt to indicate the participation impact at motivating individuals and increasing their productivity. The study rushed in the researcher opinion; that the management accountant may contribute in raising the spiritual at the employees then their productivity by preparing Budgets, which take into consideration, the behavioral sides to the employees. The researcher chose the participation method in its capacity as a side of behavior which may affect on the individual productivity. The main hypothesis that the researcher intended to test stipulated that "the participation method in preparing budget is one of the tools which help on motivating individuals toward increasing the productivity, that due to their feelings of gratification their high needs from Maslow score by impact participation".

To achieve the purposes of his study and test the hypothesis the researcher conducts field experiments through which the changing exploration is done, in the opinions of the sample's population for the degree of their gratification of needs such as respect and self accomplishment form one hand, and measure of their productivity on other hand. So the study population was represented in the general company for the cotton industry in Iraq (The Cotton Factory) in the Qadissys governorate.

The most important result of this study was the participation of employees in putting the estimates for the budgets to their activities because of the arise of their spirituality which motivate them toward the separate capacity in high performance and productivity domain, so the university budget still depend on the traditional method.

\subsection{Stephen R. Lyne Study (1998)}

This study examines the role of the budget in thirteen medium and large UK companies, where the budgets was generally used as a control device by means of calculating and investigating variance. Further, the pressures to meet the budgets came most strongly from the individual, not senior management or accountants. Also from result of this study, there was limited participation in the budget setting process in UK companies also wherever that $(86 \%)$ of sample answers see that budgets considered a tool for planning and controlling.

\subsection{Ross Snel study (1999)}

This study indicate to the rapid changes in the internet lead to bases change related by the banks business, and confusion create to traditional procedures of budgets which prepare at the end of year, and force numbers of banks in review in how to plan for its financial resources in technology projects. Thus the study of Ross indicate to that the percentage numbers of financial service companies which prepare its budget for technology planning of 125 company was in year $1997(3 \%)$, year $1998(6 \%)$, year $1999(10 \%)$ this study showed that the banks increase of its depend on budgets in planning its financial resources with more accuracy and quickness. 


\subsection{Lam K.C and Runeson G. Study (2001)}

This paper explores the current practice of capital budget planning and control in the Hong Kong (HK) construction industry, based on two surreys undertaken in 1994 and 1999. the aims of these surveys were to uncover the financial planning, monitoring and control procedures used by building engineering contractors in HK. the result of the current survey reveal that less than half the respondents undertook any form of capital budgets planning. the most common form of capital planning was a review of the minimum rate o return. Despite the low prevalence of planning, most respondents adopted some method of capital budget control, especially by way of monitoring project performance. the 1999 . the results indicate that there significant improvement in capital budget planning practice over the five year period, in addition to these findings, this paper concludes with a classification of firms, according to their capital budget planning behavior, using discriminate function analysis

\subsection{P. L. Joshi, Jawahar Al-Mudhaki and Wayne G. Bremser Study (2003)}

Examines budget planning; implementation and performance evaluation practices by utilizing a questionnaire survey of 54 medium and large sized companies located in Bahrain. Most of the companies prepare long-range plans and operating budgets, and they follow a definite budget procedure and implementation methodology. Uses budget variances to measure a manager's ability, for timely recognition of problems, and to improve the next period's budget. While both the listed and non-listed companies have reported many similar budget practices, the main differences were specific purposes served by budgets, degree of budget participation, periodicity of variance reporting, and purposes and authority to evaluate budget variance reports. In certain cases, firm size influences budgeting practices. Contributes toward filling a gap in the literature on the use of budgets as a planning and control tool in developing countries. Most prior studies were mainly confined to advanced countries. The study findings suggest the need for research on attitudes held by the budget towards the use of budget variances in the context of advanced management accounting techniques

\subsection{Turki Alhmoud and, Khalaf Al-Ta'ani study (2005)}

This study aimed to recognize the extent of the planning reality when preparing of Yarmouk university budget and put its estimates in both sides of revenues and expenditures, also it aimed to test the extent of difference between the budget and actual results which achieved at the end of the year. To do that the researchers analyzed the university budget for the financial years (1987- 2002), by using a number of statistical methods to test the extent of being statistical differences between two budgets items (actual Budget and budget articles).

The results pointed out that the university still depends on the traditional method in preparing its budget, which stands on putting the budget estimates according to the previous year's data beside the actual spending at the ending part from the financial year, during which the estimates is done. The results showed that there are important statistical differences between the estimated amounts and the actual amounts for most expenditures items, especially the capital expenditures, which reflected statistical differences, the reason was due to nonaccurate estimates because of the insufficient information which help to put correct and 
objectivity estimates, and they are unprepared estimates by the specialists in this domain, and the estimation process is left to the personal judgment. For the revenues, the results showed that there aren't statistical difference except the items of additional fees and the governmental gifts, the difference in these items were having statistical significant.

Also, the study showed that there are substantial differences in the distribution process for the financial allocations as appeared that there are expanding in repeated spending on consideration of capital expenditure and scientific research and the average spending proportion was on the final one $1 \%$ from the total of spending and that throughout the years 1987-2002.

This reflects the foundations absence on which may depend a comprehensive and complete planning for the scientific, teaching and researching programs and activities for the university. The previous affected in the budget role in planning and controlling.

\subsection{Waleed Z. Siyam Study (2009)}

This study is intended to determine how far budgets are used in planning, control and decision making in the Jordanian pharmaceutical public shareholding companies, through identifying the extent of contribution by the budgets in assisting management in performing its administrative functions and studying how such budgets are used in reality. It is also intended to find out how far the companies' management are aware of the importance of using these budgets along with the obstacles (constraints) facing the optimal use. To attain these objectives, a questionnaire was designed and handed out to the financial managers, finance and accounting department personnel of seven Jordanian pharmaceutical public shareholding companies listed at the Amman Stock Exchange (Amman Bourse) at the beginning of the year 2007. Seventy questionnaires were distributed out of which 62 questionnaires were approved for analysis and research purposes, i.e. nearly $89 \%$ of the distributed questionnaires. Results of the study showed that budgets are helpful in terms of assisting management in carrying out its administrative tasks and those companies' managements are largely aware of the importance of using such budgets in planning, control and decision making operations notwithstanding the average use of these budgets in reality. It was also found that there are numerous constraints facing the optimal use of budgets, mainly the unreliability of figures predicted and used in the budgets.

\subsection{Segun Abogun and Temitope Olamide Fagbemi study (2012)}

The effectiveness of budgeting has a link with the level of environmental volatility. It means that, how effective budgeting would be in controlling the activities of any organisation depends largely on the environmental volatility under which such budget is operated. Empirical evidence on the effect of environmental factors on budgeting and budget effectiveness in Nigeria, an emerging economy has been scanty. This gap in the literature is the focus of this study. The primary source of data was used and data were collected through the use of questionnaire. Hypotheses were formulated and tested using inferential statistics. Findings did not provide strong evidence on the effectiveness of budgeting as a control measure. This is not consistent with evidences from the developed world. The findings also 


\section{MlMacrothink}

International Journal of Accounting and Financial Reporting

reveal those factors affecting the effectiveness of budgeting in Nigeria.

\subsection{Hussein Elnafabi \& Abdulrahman Al-Twaijry study (2013)}

The aim of this study is to examine the factors that may affect the preparation of budgets in hotels sector in Almadina Alnunawara, and to highlight the principles which are considered when preparing the budget. The predicting methods for estimats revenues and expenses and the comparison between actual figures and estimations are also investigated. The data for this study were collected using a questionnaire which was distributed to the large hotels in Almadina Almunawara, Saudi Arabia. The results of this study suggest that most hotels prepare their budgets annually and also most hotels use statistical methods for predicting their revenues and expenses. The guest (customer) of the hotel was found to be the basic element for preparing the budget in more than half of hotels surveyed. On the other hand, the study revealed some negative findings regarding budgets. The most noticeable ones are that staff do not participate in preparing the budget in most hotels and about half of the hotels do not compare actuals with budgets. The study also pointed out other factors which significantly affect the types and the preparation process of budgets in hotels. These factors include hotel age, hotel size, number of accountants - especially cost accountants, hotel ranking (number of stars), ownership, participation in the budget process, approval procedures, and the budget time span.

\section{Instrument Reliability}

the reliability of the tool was examined through the Cronbach's Alpha coefficient test. Looking at table No. (1), we find that the all values of alpha are greater than (0.60) meaning that there is a reliability in the study tool.

Table No. (1) Result of cronbach alpha

\begin{tabular}{|l|l|l|}
\hline No. & Dimension & $\begin{array}{l}\text { Cronbach's } \\
\text { Alpha }\end{array}$ \\
\hline 1 & $\begin{array}{l}\text { the operating budgets are considered a quantitative and financial } \\
\text { achievement of the goals to which the administration seeks }\end{array}$ & 0.80 \\
\hline 2 & $\begin{array}{l}\text { there is an organizational and accounting structure for identifying the } \\
\text { items of the operating activities in the budgets }\end{array}$ & 0.78 \\
\hline 3 & $\begin{array}{l}\text { using budgets leads to distributing the available resources on the } \\
\text { production departments accurately }\end{array}$ & 0.75 \\
\hline 4 & $\begin{array}{l}\text { in preparing budgets, there is a standard costs system for identifying } \\
\text { the production costs as well as the operating activities }\end{array}$ & 0.71 \\
\hline Total & $\mathbf{0 . 7 8}$ \\
\hline
\end{tabular}




\section{Macrothink}

\section{Hypotheses Test}

\subsection{Hypothesis I}

The operating budgets are considered a quantitative and financial achievement of the goals to which the administration seeks.

Table No. (2) shows that all items, except for items (2 and 3) have obtained arithmetic means greater than (3.00) and observation significances less than (0.05) which indicate that they are statistically significant. They use budgets in planning the production activities in a quantitative, financial plan, and achieve budgets through using the available resources during the operating period. The quantitative and financial objectives are included in the programs' budgets so the administration department can achieve as well as achieving the cost entrepreneurship towards a distinguished competitive center.

Statements ( 2 and 3) achieved mean less than (3.00) for each that they have no statistical significance that statistical methods are not used in estimating the revenues and costs when preparing the operating budgets; the revenues budget (income) are not considered the main tool for linking all the production activities with the operating goals.

As for all the statements, the mean was (3.31) and the level of the observation significance was less than (0.05), statistically significant; this means that hypothesis I is approved where the operating budgets are a real quantitative and financial application of the objectives the administration seeks to reach.

Table No. (2) The mean, standard deviation, T values, and the levels of the significance level related to the quantitative, financial application of the objectives:

\begin{tabular}{|l|l|l|l|l|l|}
\hline No. & Statement & Mean & $\begin{array}{l}\text { Std. } \\
\text { Devi }\end{array}$ & T- value & Sig. \\
\hline 1 & $\begin{array}{l}\text { Budgets are used in planning the productive } \\
\text { activities in a quantitative, financial plan. }\end{array}$ & 42 & 1.37 & 3.75 & 0.00 \\
\hline 2 & $\begin{array}{l}\text { Statistical methods are used in estimating the } \\
\text { revenues and costs when preparing the operating } \\
\text { budgets. }\end{array}$ & 2.51 & 0.89 & -6.80 & 0.00 \\
\hline 3 & $\begin{array}{l}\text { The revenues budget (income) are considered } \\
\text { the main tool for linking all the production } \\
\text { activities with the operating objectives }\end{array}$ & 2.85 & 0.82 & -2.18 & 0.03 \\
\hline 4 & $\begin{array}{l}\text { Budgets use the available resources fully in the } \\
\text { operating period. }\end{array}$ & 3.42 & 0.82 & 6.26 & 0.00 \\
\hline 5 & $\begin{array}{l}\text { The quantitative, financial objections are set in } \\
\text { Then }\end{array}$ & 4.03 & 0.71 & 17.86 & 0.00 \\
\hline
\end{tabular}




\begin{tabular}{|l|l|l|l|l|l|}
\hline & $\begin{array}{l}\text { the budget of the programs and performance so } \\
\text { that the administration can achieve it }\end{array}$ & & & & \\
\hline 6 & $\begin{array}{l}\text { The budgets can do the quantitative, financial } \\
\text { achievement of the objectives that can achieve } \\
\text { entrepreneurship in costs towards a } \\
\text { distinguished competitive center }\end{array}$ & 3.63 & 1.20 & 6.42 & 0.00 \\
\hline Total & 3.31 & 0.57 & 6.67 & 0.00 \\
\hline
\end{tabular}

\subsection{Hypothesis II}

There is an organizational and accounting structure for identifying the items of the operating activities in the budgets:

Table No. (3) Shows that all statements, except statement \# (11) obtained means greater than (3.00) for each and significance level less than (0.05) which means that they are statistically significant. The budgets of the operation activity budgets depend on collecting, measuring and identifying the current activity; they also include the decentralization and the accounting of the organizational plan in collecting, measuring and identifying the costs of the current activity.

The organizational and accounting structure contributes in preparing budgets that achieve greater profits from the current production activity. When preparing budgets, the financial resources are grouped in the structure of the functional administrative organization that achieves controlling over the production activities. Statement No. (11) obtained mean less than (3.00) meaning that they are not statistically significant; accordingly, budgets are not prepared in organizational and accounting structure that is dependent on the profit standards in performance evaluation (growth in the revenues and operating profits).

As for all the statements, the mean was (3.69) and the observation significance level was less than (0.05), statistically significant; this entails that hypothesis II is approved where there is organizational and accounting structure to identify the items of the operating activities in the budgets.

Table No. (3) The mean, standard deviations, T values and the significance levels related to the organizational and accounting structure:

\begin{tabular}{|l|l|l|l|l|l|}
\hline No. & Statement & Mean & Std. Devi & T- value & Sig. \\
\hline 7 & $\begin{array}{l}\text { The budgets of the operating activity are } \\
\text { prepared according to an accounting structure } \\
\text { focusing on collecting, measuring and } \\
\text { determining the costs of the current activity }\end{array}$ & 4.05 & 0.87 & 14.91 & 0.00 \\
\hline
\end{tabular}




\section{Macrothink

International Journal of Accounting and Financial Reporting

ISSN 2162-3082

\begin{tabular}{|l|l|l|l|l|l|}
\hline 8 & $\begin{array}{l}\text { Decentralization and accounting are the } \\
\text { responsibility of the organizational plan in } \\
\text { collecting, measuring and determining the } \\
\text { costs of the current activity }\end{array}$ & 0.56 & 28.14 & 0.00 \\
\hline 9 & $\begin{array}{l}\text { The organizational and accounting structure } \\
\text { contributes in preparing budgets achieving } \\
\text { the highest value of the current production } \\
\text { activity }\end{array}$ & 3.27 & 1.14 & 2.85 & 0.00 \\
\hline 10 & $\begin{array}{l}\text { In preparing budgets, the financial resources } \\
\text { are collected in a functional, administrative } \\
\text { organization achieving supervision on the } \\
\text { profits of the production activities }\end{array}$ & 3.97 & 0.89 & 13.26 & 0.00 \\
\hline 11 & $\begin{array}{l}\text { budgets are prepared in an organizational and } \\
\text { accounting structure that depends on the } \\
\text { profits scales in assessing performance } \\
\text { (growth in revenues and operating profits) }\end{array}$ & 2.88 & 0.89 & -1.65 & 0.10 \\
\hline Total & $\mathbf{3 . 6 9}$ & $\mathbf{0 . 5 6}$ & $\mathbf{1 4 . 9 8}$ & $\mathbf{0 . 0 0}$ \\
\hline
\end{tabular}

\subsection{Hypothesis III}

Using budgets leads to distributing the available resources on the production departments accurately:

Table No. (4) Shows that all the statements, except statement No. (12 and 14) obtained mean greater than (3.00) for each and observation significance levels less than (0.05) which means that they are statistically significant. The budgets identify production inputs in less costs suiting the production size and measuring the financial needs of the operating inputs to enhance the proficiency of the production process in light of the available resources; budgets are prepared based on the model of the balanced performance in identifying the economic resources achieving balance in all the aspects of the operating activities.

Statements No. (12 and 14) obtained mean less than (3.00) for each that they are not statistically significance meaning that the resources are not set for the operating activities according to the operating efficiency of the administrative levels. In preparing budgets, the administration does not lie on all the administrative levels in limiting the available resources for the operating activities. As for all the levels, the mean was (3.21) and the observation significance level was less than (0.05), which means it is statistically significant; this entails that hypothesis III is approved where the use of budgets leads to distributing the resources to the production departments accurately. 


\section{Ml Macrothink}

International Journal of Accounting and Financial Reporting

ISSN 2162-3082

2016, Vol. 6, No. 2

Table No. (4) The means, standard deviations, $T$ values and the significance levels related to the distribution of the available resources on the productive departments accurately

\begin{tabular}{|c|c|c|c|c|c|}
\hline No. & Statement & Mean & $\begin{array}{l}\text { Std. } \\
\text { Devi }\end{array}$ & T- value & Sig. \\
\hline 12 & $\begin{array}{l}\text { the available resources are limited to the } \\
\text { operating activities according to the operating } \\
\text { proficiency of the administrative levels }\end{array}$ & 2.94 & 1.11 & -0.66 & 0.51 \\
\hline 13 & $\begin{array}{l}\text { through budgets, productive inputs are identified } \\
\text { in low costs suiting the production size }\end{array}$ & 3.27 & 0.82 & 4.00 & 0.00 \\
\hline 14 & $\begin{array}{l}\text { in preparing budgets, the administrations depend } \\
\text { on all the administrative levels in setting the } \\
\text { available sources to the operating activities }\end{array}$ & 2.47 & 0.58 & -11.20 & 0.00 \\
\hline 15 & $\begin{array}{l}\text { budgets are prepared on the balanced } \\
\text { performance model in setting the economic } \\
\text { resources to achieve balance in different aspects } \\
\text { of the operating activities }\end{array}$ & 3.45 & 0.92 & 5.92 & 0.00 \\
\hline 16 & $\begin{array}{l}\text { Budgets are considered a self-supervisory } \\
\text { method to direct the available sources towards } \\
\text { implementing production activities }\end{array}$ & 3.46 & 1.25 & 4.52 & 0.00 \\
\hline 17 & $\begin{array}{l}\text { Through budgets, the financial needs of the } \\
\text { operating inputs are measured to enhance the } \\
\text { efficiency of the production process in light of } \\
\text { the available sources }\end{array}$ & 3.67 & 1.26 & 6.47 & 0.00 \\
\hline \multicolumn{2}{|c|}{ Total } & 3.21 & 0.72 & 3.57 & 0.00 \\
\hline
\end{tabular}

\subsection{Hypothesis IV}

In preparing budgets, there is a standard costs system for identifying the production costs as well as the operating activities. 
Table (5): The mean, standard deviation, $\mathrm{T}$ values and the significance levels related to setting a standard costs system to identify the production costs.

\begin{tabular}{|l|l|l|l|l|l|}
\hline No. & Statement & Mean & $\begin{array}{l}\text { Std. } \\
\text { Devi }\end{array}$ & T- value & Sig. \\
\hline 18 & $\begin{array}{l}\text { The standard costs are an integral part in } \\
\text { preparing the production budget of the } \\
\text { current activity }\end{array}$ & 3.32 & 0.99 & 3.95 & 0.00 \\
\hline 20 & $\begin{array}{l}\text { Budgets are prepared through standard costs } \\
\text { system identifying the costs of the activities, } \\
\text { process and potential changes in the market }\end{array}$ & 3.88 & 0.59 & 18.27 & 0.00 \\
\hline $\begin{array}{l}\text { The standard costs contribute in providing } \\
\text { quantitative information on the expected } \\
\text { performance of all the production activities } \\
\text { in the budget }\end{array}$ & 3.75 & 0.82 & 11.14 & 0.00 \\
\hline 21 & $\begin{array}{l}\text { The budgets' items are compared with the } \\
\text { standard costs to put the correcting } \\
\text { procedures during the operating period }\end{array}$ & 3.76 & 0.77 & 12.16 & 0.00 \\
\hline 22 & $\begin{array}{l}\text { The standard costs help in planning the items } \\
\text { of the operating budgets of the production } \\
\text { processes } \\
\text { The standard costs are used in preparing the } \\
\text { aspects of the operating activities and } \\
\text { processes to calculate the required costs for } \\
\text { the production unit }\end{array}$ & 3.71 & 1.20 & 7.24 & 0.00 \\
\hline $\begin{array}{l}\text { Then } \\
\text { Then }\end{array}$ & 1.00 & 5.47 & $\mathbf{0 . 0 0}$ \\
\hline
\end{tabular}

Table No. (5) shows that all the statements have obtained mean greater than (3.00) for each and observation significance levels less than (0.05) which means that they are statistically significant. The standard costs are an integral part in preparing the production budget of the current activity; budgets are prepared through standard costs system identifying the costs of the activities, processes and potential changes in the market and they provide quantitative information on the expected performance for all the production activities in the master budget. The items of the budgets are compared with the standard costs to perform corrective procedures during the operating period; the standard costs help in planning the items of the 


\section{MInstitute Macrothink $_{\text {Int }}$}

International Journal of Accounting and Financial Reporting

ISSN 2162-3082

2016, Vol. 6, No. 2

operating budgets of the production processes and they help in preparing the budgets that achieve consistency in all the aspects of the operating processes and activities for calculating the required costs for the production unit.

As for all the statements, the mean was (3.64) and the observation significance level was less than (0.05), which means it is statistically significant; this entails that hypothesis VI is approved where a standard cost system is conducted to prepare budgets to identify the costs of the production and the operating activities.

\section{Results}

1. budgets are a financial and quantitative achievement of the objectives to which the administration seeks where they are used in planning production activities in a quantitative, financial plan; budgets use the available resources fully during the operating period; the quantitative, financial objectives are set in the programs' budget and the performance so that the administration can achieve and they apply the objectives that achieve entrepreneurship in costs towards a distinguished competitive center. However, statistical methods are not used in estimating the numbers of revenues and costs when preparing the operating budgets and the revenues' budget (income) are not considered the main tool to link all the production activities with the operating objectives.

2. There is an organizational and accounting structure to identify the items of the operating activities in the budgets, where the operation activity budgets depend on collecting, measuring and identifying the costs of the current activity; they also include the decentralization and the responsibility accounting of the organizational plan in collecting, measuring and identifying the costs of the current activity. The organizational and accounting structure contributes in preparing budgets that achieve greater profits from the current production activity. When preparing budgets, the financial resources are grouped in the structure of the functional administrative organization that achieves controlling over the profits of production activities. However, budgets are not prepared in an organizational and accounting structure that is dependent on the profit standards in performance evaluation (growth in the revenues and operating profits).

3. Using budgets leads to distributing the available resources on the productive departments accurately. The budgets identify production inputs in less costs suiting the production size and measuring the financial needs of the operating inputs to enhance the proficiency of the production process in light of the available resources; budgets are prepared based on the model of the balanced performance in identifying the economic resources achieving balance in all the aspects of the operating activities. The resources are not set for the operating activities according to the operating efficiency of the administrative levels. In preparing budgets, the administration does not lie on all the administrative levels in limiting the available resources for the operating activities. 


\section{Macrothink}

International Journal of Accounting and Financial Reporting ISSN 2162-3082 2016, Vol. 6, No. 2

4. In preparing budgets, there is a standard costs system for identifying the production costs as well as the operating activities. The standard costs are an integral part in preparing the production budget of the current activity; budgets are prepared through standard costs system identifying the costs of the activities, processes and potential changes in the market and they provide quantitative information on the expected performance for all the production activities in the budget. The items of the budgets are compared with the standard costs to perform corrective procedures during the operating period; the standard costs help in planning the items of the operating budgets of the production processes and they help in preparing the budgets that achieve consistency in all the aspects of the operating processes and activities for calculating the required costs for the each production unit.

\section{Recommendations}

1. Companies should use the statistical methods in estimating the revenues and costs when preparing the operating budgets.

2. The revenues budget (income) should be taken care of and it should be considered as the main tool for linking all the production activities with the operating objectives.

3. Budgets should be prepared in an organizational and accounting structure depending on the profits' scale in performance evaluation (growth in revenues and operating profits).

4. The available resources should be limited to the operating activities according to the operating efficiency of the administrative levels.

5. In preparing budgets, companies' administrations should depend on all the administrative levels in identifying the available resources on the operating activities.

\section{References}

Carl S. Warren and others. Accounting, 21th ed, Thomson, South Western, 2005.

Douglas W. Kieso and other. Managerial Accounting: the tools for business Decision making $3^{\text {rd }}$ ed, John Wiley and sons, united state, 2005.

Horngern T. Charles and other, Introduction to Managerial Accounting $11^{\text {th }}$ ed, prentice Hall, New jersey, 1999.

Horngren T. Charles and others. Introduction to Management Accounting, $4^{\text {th }}$ ed, Personal Education, New Jersey,2005.

Hussein Elnafabi \& Abdulrahman Al-Twaijry study, The Adoption of Budgets by Hotels: A Field Study of Almadina Almunawara, The Arab Journal of Accounting, Volume 16. Number 1, Pp 77 - 101, June 2013.

Janice. M. Roehl Anderson and Steven M. Bragg, The Controllers Function: the work of the 


\section{Macrothink}

International Journal of Accounting and Financial Reporting

managerial accountant, $3^{\text {rd }}$ ed, John Wiley, New Jersey, 2005.

Lam K.C and Runeson G. study (2001), titled :"Capital Budget Planning Practices of Building Contractors in Hong Kong".

Marriott Neil and Chandler Roy, Management Accounting: a spread sheets approach, $1^{\text {st }}$ ed, Prentice Hall, 1993.

Maryan M. Mowen and Don R. Hansen. Managerial Accounting: the cornerstone for business decisions, $1^{\text {st }}$ ed, Thomson,United State,2006 .

Moayad Al-Fadhil, Participation in Preparing Budgets is a Tool for Satisfying the High Needs for Maslow Score, and Increasing the Productivity-a testing accounting study, yarmouk journal research, Vol. 15, issue 3, 1993, pp 509 - 547.

P. L. Joshi, Jawahar Al-Mudhaki and Wayne G. Bremser study(2003), titled :" Corporate budget planning, control and performance evaluation in Bahrain"

Prasama Chandra, Financial Management: theory and practice, $6^{\text {th }}$ ed, Mc Graw- Hill, New Delhi, 2004.

Ray H. Garrison, Managerial Accounting: concepts for planning decision making, $4^{\text {th }}$ ed., Business publications, Texas, 1991.

Ronald. W.Hilton, Managerial Accounting. $4^{\text {th }}$ ed, Irwin Mc Graw-Hill, United state, 1999.

Ross Snel, Banks' Budget Planning Method are not Ready for Internet Time, American Banker, Vol. 164. issue, 227, 1999. pp2-29.

Segun Abogun and Temitope Olamide Fagbemi study, The Efficacy of Budgeting as a Control Measure in Developing Economies: A Study from Nigeria, Asian Social Science, Vol. 8, No. 1; January 2012 .

Stephen R. Lyne, The Role of Budget in Medium and large UK Companies and the Relationship with Pressure and Participation", Accounting and business research, Vol 18, No.71 (1998) pp 195- 212.

Turki Alhmoud and, Khalaf Al-Ta'ani, The Capacity and Efficiency of Planning Budgets, Yarmouk University Case", moat for studies and research, Vol. 20, Issue 4, 2005.

Vincent K. Chong \& Kar Ming Chong, Budget Goal Commitment and Informational Effects of Budget Participation on Performance: A Structural Equation Modeling Approach, Behavioral Research In Accounting, Volume 14, 2002, Printed in USA.

Waleed Z. Siyam, Extent of Using Budgets in Planning, Control and Decision Making in the Jordanian Pharmaceutical Public Shareholding Companies, studies, administrative science, Vol. 36, No. 2, 2009. 


\section{Macrothink \\ International Journal of Accounting and Financial Reporting \\ ISSN 2162-3082}

\section{Copyright Disclaimer}

Copyright for this article is retained by the author(s), with first publication rights granted to the journal.

This is an open-access article distributed under the terms and conditions of the Creative Commons Attribution license (http://creativecommons.org/licenses/by/3.0/). 